\title{
Recent advances in molecular genetics of melanoma
}

\section{progression: implications for diagnosis and treatment}

\section{[version 1; peer review: 3 approved]}

\section{Iwei Yeh}

Department of Dermatology, University of California San Francisco, San Francisco, CA, USA

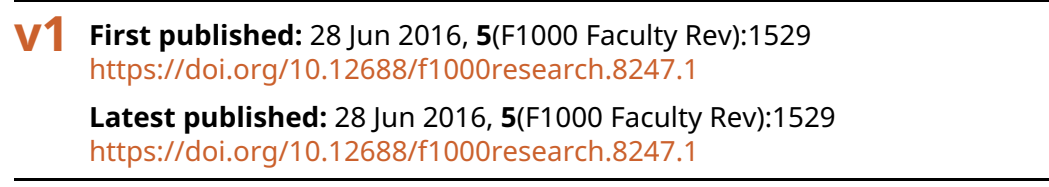

\section{Abstract}

According to the multi-step carcinogenesis model of cancer, initiation results in a benign tumor and subsequent genetic alterations lead to tumor progression and the acquisition of the hallmarks of cancer. This article will review recent discoveries in our understanding of initiation and progression in melanocytic neoplasia and the impact on diagnostic dermatopathology.

Keywords

melanoma, dermatopathology, melanocytic neoplasia , BRAFV600E , BRAF , nevi , Spitz nevi

\section{Open Peer Review}

Approval Status

1

2

3

version 1

28 Jun 2016

Faculty Reviews are review articles written by the prestigious Members of Faculty Opinions. The articles are commissioned and peer reviewed before publication to ensure that the final, published version is comprehensive and accessible. The reviewers who approved the final version are listed with their names and affiliations.

1. Heinz Kutzner, Dermatopathologie Friedrichshafen, Friedrichshafen, Germany

2. Lyn Duncan, Massachusetts General Hospital and Harvard Medical School, Boston, USA

3. Pedram Gerami, Northwestern University, Chicago, USA

Any comments on the article can be found at the end of the article. 
Corresponding author: Iwei Yeh (yehi@derm.ucsf.edu)

Competing interests: The author declares that she has no competing interests.

Grant information: The author(s) declared that no grants were involved in supporting this work.

Copyright: @ 2016 Yeh I. This is an open access article distributed under the terms of the Creative Commons Attribution License, which permits unrestricted use, distribution, and reproduction in any medium, provided the original work is properly cited.

How to cite this article: Yeh I. Recent advances in molecular genetics of melanoma progression: implications for diagnosis and treatment [version 1; peer review: 3 approved] F1000Research 2016, 5(F1000 Faculty Rev):1529

https://doi.org/10.12688/f1000research.8247.1

First published: 28 Jun 2016, 5(F1000 Faculty Rev):1529 https://doi.org/10.12688/f1000research.8247.1 


\section{Initiating oncogenes in melanocytic neoplasia}

If an initiating oncogene causes tumor formation, it should be present clonally in benign neoplasms and occur in a mutually exclusive pattern with other initiating events. $\mathrm{BRAF}^{\mathrm{V} 600 \mathrm{E}}$ satisfies these criteria in melanocytic neoplasia. Studies demonstrate that $B R A F$ mutations are typically present in all or none of the cells within nevi and melanomas ${ }^{1,2}$. In a recent study of the genetic evolution of melanoma, sequencing of known oncogenes in melanoma and cancer did not reveal additional driver alterations in unequivocally benign nevi with $\mathrm{BRAF}^{\mathrm{V} 600 \mathrm{E}}$, additionally supporting the hypothesis that $\mathrm{BRAF}^{\mathrm{V} 600 \mathrm{E}}$ mutation can initiate melanocytic nevi ${ }^{3}$.

The set of probable initiating oncogenes in melanocytic tumors includes activating point mutations in $B R A F, N R A S, G N A Q, G N A 11$, and activating fusions of $B R A F$ and the receptor tyrosine kinases (RTKs) ALK, ROS1, RET, MET, and NTRK1. These mutations have been identified in benign and malignant melanocytic tumors in a mutually exclusive pattern, e.g. only one of these MAPK-activating mutations will be present. While KIT mutations do not co-occur with probable initiating oncogenes, they have not been identified in benign melanocytic tumors and it is unclear when activating KIT mutations arise during melanoma progression.

Initiating oncogenes may influence tumor phenotype. Different histopathologic subtypes of nevi demonstrate varying spectra of initiating mutations. Common acquired nevi harbor BRAF ${ }^{\mathrm{V} 600 \mathrm{E}}$ mutations in $\sim 85 \%$ of cases with activating NRAS mutations in $3-5 \%$. The majority of blue nevi harbor activating mutations in one of two highly homologous members of the G-alpha $\mathrm{Q}$ family, GNAQ $(65 \%)$ and GNA11 (9\%) $)^{5,6}$. Spitz nevi have the most diverse set of initiating mutations with activating HRAS mutations (22\%) and activating fusions of BRAF (7\%) and the RTKs $A L K(12 \%)$, $\operatorname{MET}(2 \%), \operatorname{NTRK1}(12 \%), \operatorname{RET}(4 \%)$, and ROS1 (25\%) ${ }^{7-10}$.

Perhaps the phenotypic differences between common acquired nevi and blue nevi are due to their distinct initiating oncogenes. If so, the diversity of initiating oncogenes in Spitz nevi and tumors could explain the phenotypic variability and the diagnostic challenges of this class of tumors. Initial studies suggest that fusions of specific RTKs may result in specific histopathologic features. Specifically, Spitz tumors with ALK fusions commonly have distinctive vertically oriented plexiform nests of fusiform melanocytes ${ }^{11,12}$. Classification of Spitz tumors by the category of initiating oncogene may result in more refined histopathologic diagnostic criteria. One caveat is the diversity within a given class of fusion kinases. Structural rearrangements lead to oncogenic RTK fusion genes because the $\mathrm{N}$-terminal fusion partner replaces the regulatory portion of the RTK. Without the regulatory domain, the kinase domain is constitutively active. Early findings indicate that activating fusions of the same RTK may be highly diverse in melanocytic tumors with a broad range of $\mathrm{N}$-terminal partners fused to variable portions of the $\mathrm{RTK}^{8-10}$. The N-terminal partner influences expression, localization, and dimerization of the fusion kinase, all features expected to impact oncogenic signaling and thus potentially tumor phenotype.

\section{Progression events}

The accumulation of oncogenic events in addition to an initiating event leads to melanoma. Owing to the high number of mutations observed in melanoma, distinguishing driver from passenger events is difficult and requires functional validation. Through large-scale sequencing studies, many progression events have been nominated in melanoma, but the functional consequences of most of them remain to be determined ${ }^{13-15}$. Understanding how combinations of oncogenic mutations interact and predict biologic behavior is an area of active investigation.

First identified in 2012 in familial and sporadic cutaneous melanoma, TERT promoter mutations result in a de novo E26 transformation-specific (ETS) factor binding site and increased TERT expression ${ }^{16-18}$. TERT is the enzymatic subunit of telomerase, and elevated telomerase activity prevents critical telomere shortening with cell division and bypasses replicative senescence. TERT promoter mutations are associated with worse prognosis in non-acral cutaneous melanoma and Spitzoid melanoma ${ }^{19,20}$.

A recent study of melanoma progression characterized various portions of melanocytic tumors that contained benign, intermediate, and malignant areas (melanoma arising within a nevus). TERT promoter mutations were identified in several "likely benign" intermediate melanocytic tumors and melanomas ${ }^{3}$. The presence of TERT promoter mutations in combination with either BRAF or NRAS activating mutations in "likely benign" intermediate tumors suggests that these combinations of oncogenic mutations are not sufficient for malignant transformation. This finding demonstrates that an intermediate category of melanocytic neoplasia exists and corresponds with existing histopathologic classifications.

A recent study identified a novel mechanism that results in translation of the kinase portion of an RTK without its corresponding regulatory domain. A novel transcript of $A L K$ transcribed from an alternative transcription initiation (ATI) site in intron 19 of the fulllength isoform of $A L K$ encodes the kinase domain of ALK without the extracellular or transmembrane regions. Present in $\sim 3-11 \%$ of melanomas, ALK ${ }^{\mathrm{ATI}}$ is not associated with DNA sequence alterations of $A L K$. Rather, it appears that the expression of ALK ${ }^{\text {ATI }}$ occurs due to epigenetic modification. In vitro, ALK $^{\mathrm{ATI}}$ constitutively activates MAPK, AKT, and STAT3 signaling and is inhibited by small molecule ALK inhibitors. While the signaling output of ALK ${ }^{\text {ATI }}$ is similar to that of ALK fusions, ALK ${ }^{\text {ATI }}$ is seen in melanomas with and without activating $B R A F$ and NRAS mutations, indicating that it is not an initiating event ${ }^{21}$.

Biallelic $B A P 1$ loss can in many cases be distinctly identified by histopathologic examination. BAP1 is a histone deubiquitinase that functions as a tumor suppressor. It is recurrently inactivated in uveal melanoma ${ }^{22}$. Germline loss-of-function variants increase the risk of melanoma, renal cell carcinoma, mesothelioma, and other cancers $^{23,24}$. The distinctive cutaneous melanocytic tumors in patients with $B A P 1$ germline mutations are characterized by dermal epithelioid melanocytes with abundant eosinophilic cytoplasm and variably enlarged, pleomorphic, and eccentrically placed nuclei, often in a background of lymphocytic inflammation. These neoplasms harbor activating $B R A F$ or NRAS mutations in addition to biallelic loss of $B A P 1$ and an adjacent common acquired nevus is often appreciated $^{25,26}$. These findings are consistent with clonal expansion of a neoplastic melanocyte in a common acquired nevus (with $B R A F$ 
or NRAS activating mutation) after biallelic loss of $B A P 1$. Based on their cytomorphology, epithelioid tumors with BAPl loss were historically classified as atypical Spitz tumors or halo Spitz nevi, both considered to have negligible to low malignant potential.

Epithelioid tumors with $B A P 1$ loss (or Wiesner nevi) are distinct from other genetic categories of Spitz nevi in that three oncogenic mutations have occurred (activating BRAF or NRAS mutation and two hits to BAPl) in contrast to Spitz nevi with $H R A S$ mutation or kinase fusions. Their characteristic cytomorphology is due to a progression event (loss of $B A P 1$ ) rather than a direct effect of the initiating oncogene, as is hypothesized for other Spitz nevi. Thus, there is an argument to be made to cleave these tumors from the Spitz progression series and add them as a subtype of intermediate tumor on the BRAF/NRAS progression series.

Early observations indicate that $B A P 1$ loss in combination with $B R A F$ or NRAS mutation gives rise to a low-risk melanocytic tumor (a topic worthy of further investigation). In contrast, BAP1 loss in combination with GNAQ or GNA11 has not been identified in low-risk melanocytic tumors but occurs in uveal melanoma and melanoma arising in blue nevi (MABN) ${ }^{22,27}$. Loss of BAPl is associated with poor prognosis in uveal melanoma ${ }^{28}$. Thus, the contribution of $B A P 1$ loss to malignant transformation in melanoma appears to differ depending on the initiating oncogene. Our models of melanoma progression will need to accommodate this complexity.

\section{Genomic reflections of aberrant cellular processes}

Arm-level and whole chromosome gains and losses, as well as focal amplifications and deletions of the genome, are frequent in melanoma and uncommon in nevi. Copy number aberrations (CNAs), particularly when multiple, may reflect previous or ongoing genomic instability. Genomic instability can result from multiple disrupted biologic processes (oncogene-induced replicative stress, defective DNA damage response, or impaired cell cycle checkpoints).

The overrepresentation of specific copy number alterations in melanoma indicates selective advantage for specific CNAs (i.e. loss of $C D K N 2 A$ or amplification of $C C N D 1$ ) and a role in tumor progression. Melanomas arising on chronically sun-damaged skin, non-chronically sun-damaged skin, acral glabrous skin, and mucosal epithelium have different patterns of CNAs, suggesting different causes of genomic instability and/or different pathways of genetic evolution $^{29}$. Not all types of melanoma demonstrate a high frequency of CNAs: for example, desmoplastic melanomas have few CNAs and a high number of single base substitutions ${ }^{30}$.

While CNAs may reflect genomic instability, they can also result from stochastic events in the absence of a long-term cellular state of global genomic instability. These events include double-stranded DNA breaks and catastrophic events that lead to complex genomic rearrangements, such as chromothripsis ${ }^{31}$. In benign or low-grade melanocytic tumors, such a chance event is thought to give rise to CNAs that lead to selective advantage and selection. Gain of chromosome $11 \mathrm{p}$ is often observed in HRAS mutant Spitz nevi ${ }^{7}$. Monosomy 3 or focal loss including $3 \mathrm{p} 21$ is often observed in epithelioid tumors with biallelic loss of $B A P 1^{23,25}$. Identification of these isolated CNAs in the context of a tumor with the expected histopathologic characteristics does not lead to a diagnosis of melanoma. Copy number transitions within kinases may indicate a kinase fusion. Often times we observe probable "passenger" structural variants in the vicinity of kinase fusions (for example, the reciprocal fusion junction). The clinical significance of varying patterns of copy number alterations seen in association with kinase fusions remains to be determined.

\section{Molecular assessment for diagnosis}

Assessment of copy number status has been used to supplement the histopathologic assessment of diagnostically challenging melanocytic tumors for over a decade. Array comparative genomic hybridization (aCGH) and fluorescence in situ hybridization (FISH) are in routine use by several diagnostic laboratories. One of the first FISH tests proposed for melanoma diagnosis employs four probes, assessing for gains of $C C N D 1$ and absolute or relative gain of $6 \mathrm{p}$ or loss of $6 \mathrm{q}$ as compared to centromere $6^{32,33}$. Additional FISH probes have been proposed for specific subtypes of melanocytic tumors $(9 \mathrm{p} 21$ to assess for homozygous $C D K N 2 A$ deletion in spitzoid tumors and $8 \mathrm{q} 24$ MYC gain to improve sensitivity in nevoid melanomas) $)^{34,35}$.

aCGH gives a broader assessment of copy number status but is less sensitive in the setting of low tumor purity and for subclonal CNAs and also requires more tissue than FISH. The patterns of CNAs are varied and the significance of a limited number of CNAs that are not common in melanoma remains to be determined. The copy number profile can provide clues to oncogenic alterations. For example, KIT amplification is often associated with KIT mutation, and copy number transitions in kinases with relative gain of the kinase portion of the gene may indicate an activating kinase fusion.

Initial studies highlight the promise of assessment of combinations of genetic alterations and expression profiles using multiplex analysis of DNA or RNA in the diagnosis of melanocytic neoplasia ${ }^{3,36}$. Additional studies with clinical follow-up and stratification by histopathologic and genetic subtype will inform how best to integrate these complex tests into current clinical practice.

\section{Molecular assessment for treatment selection}

Currently, the two major approaches to the treatment of metastatic melanoma are immunotherapy and molecularly targeted therapies, and there are studies underway to evaluate combination regimens. The checkpoint inhibitors ipilimumab (anti CTLA-4 antibody), nivolumab, and pembrolizumab (anti PD-1 antibodies) result in objective responses in 10-40\% of patients and an overall survival benefit ${ }^{37-40}$. PD-L1 expression correlates with response to anti PD-1 antibodies, and the combination of nivolumab and ipilimumab improves response rates in PD-L1-negative tumors. As the side effect profile of checkpoint inhibitors is not insignificant, work is currently ongoing to identify which patients will benefit from these treatments. In non-small-cell lung cancer, a higher mutation burden (likely a proxy for increased neoantigens) is associated with improved response to immunotherapy ${ }^{41}$. Estimation of mutation burden, neoantigen expression, or expression profile may refine therapy selection for metastatic melanoma in the near future ${ }^{42}$. 
Targeted therapy of BRAF ${ }^{\mathrm{V} 600 \mathrm{E}}$ mutant melanoma with inhibitors of mutant $B R A F$ is currently part of the standard of care. Combination with MEK inhibitors improves outcomes ${ }^{43,44}$. Approximately $50 \%$ of metastatic melanomas harbor a $B R A F$ mutation, $\sim 25 \%$ harbor an activating NRAS mutation, and 3-5\% harbor an activating KIT mutation. Inhibitors of NRAS are currently unavailable, but initial clinical trials of MEK inhibitors in NRAS mutant melanomas show some efficacy ${ }^{45}$. Dramatic responses to KIT inhibitors such as imatinib and nilotinib have been observed in patients with KIT mutant melanoma ${ }^{46-50}$.

In a minority of cutaneous melanoma patients, an activating mutation in BRAF, NRAS, or KIT is not identified. In these patients, testing for a kinase fusion may yield a potential therapeutic target. In case reports of patients with $B R A F$ fusion melanoma, responses to sorafenib and trametinib were observed ${ }^{8,51,52}$. Treatment of other solid tumors with RTK fusions similar to those observed in melanoma provides clinical benefit as exemplified by ALK inhibition in lung cancer with ALK fusions ${ }^{53,54}$. Clinical studies are needed to assess the efficacy of kinase inhibitors for kinase fusion melanoma.

There are an increasing number of diagnostic modalities available for the detection of actionable and potentially actionable genetic alterations. Considerations for selecting specific assays include cost, turn-around time, comprehensiveness for actionable alterations (a moving target), and specimen requirements. For point mutations, immunohistochemistry (VE1 for BRAF ${ }^{\mathrm{V} 600 \mathrm{E}}$ and SP174 for NRAS ${ }^{\mathrm{Q} 61 \mathrm{R}}$ ) and allele-specific real-time polymerase chain reaction (RT-PCR) assays (cobas ${ }^{\circledR} 4800$ BRAF V600) provide quick, highly sensitive, and easy-to-interpret assessment for a narrow spectrum of mutations ${ }^{55-57}$. Sanger sequencing has been traditionally used for the detection of hotspot mutations in oncogenes and can detect mutations within the assayed region (i.e. $B R A F$ exon 15). One limitation of Sanger sequencing is a limit of detection of $\sim 10-20 \%$ minor allele frequency (corresponding to $20-40 \%$ tumor fraction in a heterozygous sample), resulting in decreased sensitivity for samples with low tumor fraction. Next-generation multiplex sequencing is being increasingly adopted as a way to perform multiplex testing of oncogenes with a lower limit of detection owing to the ability to sequence individual DNA molecules. Next-generation sequencing (NGS) cancer testing platforms typically assess a panel of oncogenes that are of interest in many types of cancer. By broadening the regions of the genome assayed, these panels may detect alterations that are actionable in other cancer types and rare in melanoma. These assays can also detect CNAs.

One can take advantage of the mutual exclusivity of actionable alterations and their prevalence in melanoma to perform stratified testing of a tumor sample. Given the high rate of BRAF V600 mutations, V600E-specific testing (immunohistochemistry or realtime based assay) or BRAF exon 15 testing (Sanger) followed by a test for a broader panel of oncogenes (including NRAS and KIT) if a BRAF mutation is not detected could optimize cost and turnaround time for melanoma patients, depending on testing strategies employed.

Identification of kinase fusions requires different approaches than the detection of oncogenic hotspot mutations, as the genomic breakpoints usually occur in intronic regions that span a much larger portion of the genome than hotspot coding mutations. Detection of fusion transcripts by RT-PCR is highly sensitive (i.e. BCR-ABL in chronic myelogenous leukemia), but RT-PCR is not practical for detecting the broad spectrum of kinase fusions that occur in melanoma. Immunohistochemistry to assess the expression of the kinase domain of ALK, ROS1, NTRK1, and MET appear to be highly sensitive for detecting fusion kinases but with varying specificity. The lack of specificity can be due to basal expression of the kinase in melanocytes (NTRK1 and MET) and alterative oncogenic mechanisms that lead to expression of the kinase domain $\left(\mathrm{ALK}^{\mathrm{ATI}}\right)$. Hybrid-capture-based NGS DNA assays can detect structural rearrangements that lead to oncogenic fusions by sequencing the introns in which the breakpoints occur and can be multiplexed with detection of other melanoma oncogenes, but this method has limited sensitivity due to repetitive regions within introns and the technical difficulty of identifying structural rearrangements from short-read sequencing. Multiplex RNAbased methods are more sensitive. FISH break-apart probes are also available for fusion detection.

\section{Future directions}

The rapid pace of technologic development has led to a remarkable expansion of our understanding of the genetic progression of cancer and melanoma. Translation of these findings into the clinic is exceeding at a rapid pace. As always, we are treating patients with the best information we have on hand while pushing for additional studies to support our current best practices in diagnosis and treatment. Refining our understanding and models of genetic progression will help us develop the best clinical and biologic hypotheses to direct future investigation.

\section{Competing interests}

The author declares that she has no competing interests.

\section{Grant information}

The author(s) declared that no grants were involved in supporting this work.
1. Yeh I, von Deimling A, Bastian BC: Clonal BRAF mutations in melanocytic nevi and initiating role of BRAF in melanocytic neoplasia. $J$ Natl Cancer Inst. 2013. 105(12): 917-9.

PubMed Abstract | Publisher Full Text | Free Full Text

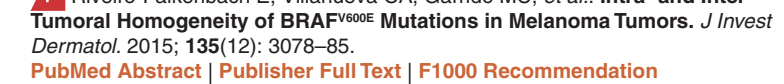


3. F Shain AH, Yeh I, Kovalyshyn I, et al.: The Genetic Evolution of Melanoma from Precursor Lesions. N Engl J Med. 2015; 373(20): 1926-36. PubMed Abstract | Publisher Full Text | F1000 Recommendation

4. Pollock PM, Harper UL, Hansen KS, et al.: High frequency of BRAF mutations in nevi. Nat Genet. 2003; 33(1): 19-20.

PubMed Abstract | Publisher Full Text

5. F Van Raamsdonk CD, Bezrookove V, Green G, et al.: Frequent somatic mutations of GNAQ in uveal melanoma and blue naevi. Nature. 2009; 457(7229):

599-602.
PubMed Abstract | Publisher Full Text | Free Full Text | F1000 Recommendation

6. F Van Raamsdonk CD, Griewank KG, Crosby MB, et al.: Mutations in GNA11 in uveal melanoma. N Engl J Med. 2010; 363(23): 2191-9.

PubMed Abstract | Publisher Full Text | Free Full Text | F1000 Recommendation

7. Bastian BC, LeBoit PE, Pinkel D: Mutations and copy number increase of HRAS in Spitz nevi with distinctive histopathological features. Am J Pathol. 2000; 157(3): 967-72.

PubMed Abstract | Publisher Full Text | Free Full Text

8. Botton $\mathrm{T}$, Yeh I, Nelson T, et al.: Recurrent BRAF kinase fusions in melanocytic tumors offer an opportunity for targeted therapy. Pigment Cell Melanoma Res. 2013; 26(6): 845-51.

PubMed Abstract | Publisher Full Text | Free Full Text

9. $\quad \mathrm{F}$ Wiesner $\mathrm{T}, \mathrm{He} \mathrm{J}$, Yelensky R, et al:: Kinase fusions are frequent in Spitz tumours and spitzoid melanomas. Nat Commun. 2014: 5: 3116.

PubMed Abstract | Publisher Full Text | Free Full Text | F1000 Recommendation

10. Yeh I, Botton T, Talevich E, et al.: Activating MET kinase rearrangements in melanoma and Spitz tumours. Nat Commun. 2015; 6: 7174

PubMed Abstract | Publisher Full Text | Free Full Text

11. $\mathrm{F}$ Busam $\mathrm{KJ}$, Kutzner $\mathrm{H}$, Cerroni $\mathrm{L}$, et al.: Clinical and pathologic findings of Spitz nevi and atypical Spitz tumors with ALK fusions. Am J Surg Pathol. 2014; 38(7): 925-33.

PubMed Abstract | Publisher Full Text | F1000 Recommendation

12. Yeh I, de la Fouchardiere A, Pissaloux D, et al.: Clinical, histopathologic, and genomic features of Spitz tumors with ALK fusions. Am J Surg Pathol. 2015; 39(5): 581-91.

PubMed Abstract | Publisher Full Text | Free Full Text

13. $\mathrm{F}$ Krauthammer $\mathrm{M}$, Kong $\mathrm{Y}, \mathrm{Ha} \mathrm{BH}$, et al.: Exome sequencing identifies recurrent somatic RAC1 mutations in melanoma. Nat Genet. 2012; 44(9): 1006-14. PubMed Abstract | Publisher Full Text | Free Full Text | F1000 Recommendation

14. F Hodis E, Watson IR, Kryukov GV, et al: $\mathbf{A}$ landscape of driver mutations in melanoma. Cell. 2012; 150(2): 251-63.

PubMed Abstract | Publisher Full Text | Free Full Text | F1000 Recommendation

15. F Cancer Genome Atlas Network: Genomic Classification of Cutaneous Melanoma. Cell. 2015; 161(7): 1681-96.

PubMed Abstract | Publisher Full Text | Free Full Text | F1000 Recommendation

16. F Huang FW, Hodis E, Xu MJ, et al.: Highly recurrent TERT promoter mutations in human melanoma. Science. 2013; 339(6122): 957-9. PubMed Abstract | Publisher Full Text | Free Full Text | F1000 Recommendation

17. F Horn S, Figl A, Rachakonda PS, et al:: TERT promoter mutations in familial and sporadic melanoma. Science. 2013; 339(6122): 959-61. PubMed Abstract | Publisher Full Text | F1000 Recommendation

18. F Bell RJ, Rube HT, Kreig A, et al.: Cancer. The transcription factor GABP selectively binds and activates the mutant TERT promoter in cancer. Science. 2015; 348(6238): 1036-9.

PubMed Abstract | Publisher Full Text | Free Full Text | F1000 Recommendation

19. F Griewank KG, Murali R, Puig-Butille JA, et al: TERT promoter mutation status as an independent prognostic factor in cutaneous melanoma. $J$ Natl Cancer Inst. 2014; 106(9): pii: dju246.

PubMed Abstract | Publisher Full Text | Free Full Text | F1000 Recommendation

20. F Lee S, Barnhill RL, Dummer R, et al.: TERT Promoter Mutations Are Predictive of Aggressive Clinical Behavior in Patients with Spitzoid Melanocytic Neoplasms. Sci Rep. 2015; 5: 11200.

PubMed Abstract | Publisher Full Text | Free Full Text | F1000 Recommendation

21. F Busam KJ, Villain RE, Lum T, et al.: Primary and Metastatic Cutaneous Melanomas Express ALK Through Alternative Transcriptional Initiation. Am J Surg Pathol. 2016; 40(6): 786-95.

PubMed Abstract | Publisher Full Text | F1000 Recommendation

22. F Harbour JW, Onken MD, Roberson ED, et al.: Frequent mutation of BAP1 in metastasizing uveal melanomas. Science. 2010; 330(6009): 1410-3. PubMed Abstract | Publisher Full Text | Free Full Text | F1000 Recommendation

23. F Wiesner T, Obenauf AC, Murali R, et al.: Germline mutations in BAP1 predispose to melanocytic tumors. Nat Genet. 2011; 43(10): 1018-21. PubMed Abstract | Publisher Full Text | Free Full Text | F1000 Recommendation

24. F Ohar JA, Cheung M, Talarchek J, et al.: Germline BAP1 Mutational Landscape of Asbestos-Exposed Malignant Mesothelioma Patients with Family History of Cancer. Cancer Res. 2016; 76(2): 206-15

PubMed Abstract | Publisher Full Text | Free Full Text | F1000 Recommendation

25. Yeh I, Mully TW, Wiesner T, et al.: Ambiguous melanocytic tumors with loss of 3p21. Am J Surg Pathol. 2014; 38(8): 1088-95

PubMed Abstract | Free Full Text

26. F Wiesner T, Murali R, Fried I, et al: A distinct subset of atypical Spitz tumors is characterized by BRAF mutation and loss of BAP1 expression. Am J Surg Pathol. 2012; 36(6): 818-30.

PubMed Abstract | Publisher Full Text | Free Full Text | F1000 Recommendation

27. F Costa S, Byrne M, Pissaloux D, et al.: Melanomas Associated With Blue Nevi or Mimicking Cellular Blue Nevi: Clinical, Pathologic, and Molecular Study of 11 Cases Displaying a High Frequency of GNA11 Mutations, BAP1 Expression Loss, and a Predilection for the Scalp. Am J Surg Pathol. 2016; 40(3): 368-77. PubMed Abstract | Publisher Full Text | F1000 Recommendation

28. F Kalirai H, Dodson A, Fagir S, et al.: Lack of BAP1 protein expression in uveal melanoma is associated with increased metastatic risk and has utility in routine prognostic testing. Br J Cancer. 2014; 111(7): 1373-80. PubMed Abstract | Publisher Full Text | Free Full Text | F1000 Recommendation

29. F Curtin JA, Fridlyand J, Kageshita T, et al.: Distinct sets of genetic alterations in melanoma. N Engl J Med. 2005; 353(20): 2135-47.

PubMed Abstract | Publisher Full Text | F1000 Recommendation

30. Shain $\mathrm{AH}$, Garrido $\mathrm{M}$, Botton $\mathrm{T}$, et al.: Exome sequencing of desmoplastic melanoma identifies recurrent NFKBIE promoter mutations and diverse activating mutations in the MAPK pathway. Nat Genet. 2015; 47(10): 1194-9. PubMed Abstract | Publisher Full Text | Free Full Text

31. Forment JV, Kaidi A, Jackson SP: Chromothripsis and cancer: causes and consequences of chromosome shattering. Nat Rev Cancer. 2012; 12(10): $663-70$.

PubMed Abstract | Publisher Full Tex

32. $\mathrm{F}$ Gerami $\mathrm{P}$, Jewell SS, Morrison LE, et al:: Fluorescence in situ hybridization (FISH) as an ancillary diagnostic tool in the diagnosis of melanoma. Am J Surg Pathol. 2009; 33(8): 1146-56.

PubMed Abstract | Publisher Full Text | F1000 Recommendation

33. F March J, Hand M, Truong A, et al:: Practical application of new technologies or melanoma diagnosis: Part II. Molecular approaches. J Am Acad Dermatol. 2015; 72(6): 943-58; quiz 959-60.

PubMed Abstract | Publisher Full Text | F1000 Recommendation

34. F Gerami P, Scolyer RA, Xu X, et al.: Risk assessment for atypical spitzoid melanocytic neoplasms using FISH to identify chromosomal copy number aberrations. Am J Surg Pathol. 2013; 37(5): 676-84. PubMed Abstract | Publisher Full Text | F1000 Recommendation

35. F Yélamos O, Busam KJ, Lee C, et al:: Morphologic clues and utility of fluorescence in situ hybridization for the diagnosis of nevoid melanoma. J Cutan Pathol. 2015; 42(11): 796-806.

PubMed Abstract | Publisher Full Text | F1000 Recommendation

36. F Clarke LE, Warf MB, Flake DD 2nd, et al.: Clinical validation of a gene expression signature that differentiates benign nevi from malignant melanoma. J Cutan Pathol. 2015; 42(4): 244-52.

PubMed Abstract | Publisher Full Text | F1000 Recommendation

37. F Larkin J, Chiarion-Sileni V, Gonzalez R, et al:: Combined Nivolumab and pilimumab or Monotherapy in Untreated Melanoma. N Engl J Med. 2015; 373(1): 23-34

PubMed Abstract | Publisher Full Text | F1000 Recommendation

38. F Hodi FS, O'Day SJ, McDermott DF, et al:: Improved survival with ipilimumab in patients with metastatic melanoma. N Engl J Med. 2010; 363(8): 711-23. PubMed Abstract | Publisher Full Text | Free Full Text | F1000 Recommendation

39. F Robert C, Long GV, Brady B, et al:: Nivolumab in previously untreated melanoma without BRAF mutation. N Engl J Med. 2015; 372(4): 320-30. PubMed Abstract | Publisher Full Text | F1000 Recommendation

40. F Robert C, Schachter J, Long GV, et al.: Pembrolizumab versus Ipilimumab in Advanced Melanoma. N Engl J Med. 2015; 372(26): 2521-32. PubMed Abstract | Publisher Full Text | F1000 Recommendation

41. F Rizvi NA, Hellmann MD, Snyder A, et al:: Cancer immunology. Mutational andscape determines sensitivity to PD-1 blockade in non-small cell lung cancer. Science. 2015; 348(6230): 124-8

PubMed Abstract | Publisher Full Text | F1000 Recommendation

42. F Spranger S, Bao R, Gajewski TF: Melanoma-intrinsic $\beta$-catenin signalling prevents anti-tumour immunity. Nature. 2015; 523(7559): 231-5. PubMed Abstract | Publisher Full Text | F1000 Recommendation

43. F Long GV, Weber JS, Infante JR, et al.: Overall Survival and Durable Responses in Patients With BRAF V600-Mutant Metastatic Melanoma Receiving Dabrafenib Combined With Trametinib. J Clin Oncol. 2016; 34(8): 871-8. PubMed Abstract | Publisher Full Text | F1000 Recommendation

44. F Larkin J, Ascierto PA, Dréno B, et al:: Combined vemurafenib and cobimetinib in BRAF-mutated melanoma. N Engl J Med. 2014; 371(20): 1867-76. PubMed Abstract | Publisher Full Text | F1000 Recommendation

45. F Ascierto PA, Schadendorf D, Berking C, et al.: MEK162 for patients with advanced melanoma harbouring NRAS or Val600 BRAF mutations: a nonrandomised, open-label phase 2 study. Lancet Oncol. 2013; 14(3): 249-56. PubMed Abstract | Publisher Full Text | F1000 Recommendation 
Handolias D, Hamilton AL, Salemi R, et al.: Clinical responses observed with imatinib or sorafenib in melanoma patients expressing mutations in $K I T$. Br J Cancer. 2010; 102(8): 1219-23.

PubMed Abstract | Publisher Full Text | Free Full Text

47. Hodi FS, Corless CL, Giobbie-Hurder A, et al:: Imatinib for melanomas harboring mutationally activated or amplified $K I T$ arising on mucosal, acral, and chronically sun-damaged skin. J Clin Oncol. 2013; 31(26): 3182-90. PubMed Abstract | Publisher Full Text | Free Full Text

48. F Guo J, Si L, Kong Y, et al:: Phase II, open-label, single-arm trial of imatinib mesylate in patients with metastatic melanoma harboring c-Kit mutation or amplification. J Clin Oncol. 2011; 29(21): 2904-9.

PubMed Abstract | Publisher Full Text | F1000 Recommendation

49. Kim KB, Eton O, Davis DW, et al:: Phase II trial of imatinib mesylate in patients with metastatic melanoma. Br J Cancer. 2008; 99(5): 734-40. PubMed Abstract | Publisher Full Text | Free Full Text

50. F Carvajal RD, Lawrence DP, Weber JS, et al:: Phase II Study of Nilotinib in Melanoma Harboring KIT Alterations Following Progression to Prior KIT Inhibition. Clin Cancer Res. 2015; 21(10): 2289-96.

PubMed Abstract | Publisher Full Text | F1000 Recommendation

51. Passeron T, Lacour J, Allegra M, et al.: Signalling and chemosensitivity assays in melanoma: is mutated status a prerequisite for targeted therapy? Exp Dermatol. 2011; 20(12): 1030-2.

PubMed Abstract | Publisher Full Text

52. Menzies AM, Yeh I, Botton T, et al.: Clinical activity of the MEK inhibitor trametinib in metastatic melanoma containing BRAF kinase fusion. Pigment Cell Melanoma Res. 2015; 28(5): 607-10.

PubMed Abstract | Publisher Full Text | Free Full Text

53. Shaw AT, Yeap BY, Solomon BJ, et al.: Effect of crizotinib on overall survival in patients with advanced non-small-cell lung cancer harbouring $A L K$ gene rearrangement: a retrospective analysis. Lancet Oncol. 2011; 12(11): 1004-12.

PubMed Abstract | Publisher Full Text | Free Full Text

54. F Shaw AT, Engleman JA: Ceritinib in ALK-rearranged non-small-cell lung cancer. N Engl J Med. 2014; 370(26): 2537-9.

PubMed Abstract | Publisher Full Text | F1000 Recommendation

55. Capper D, Preusser M, Habel A, et al:: Assessment of BRAF V600E mutation status by immunohistochemistry with a mutation-specific monoclonal antibody. Acta Neuropathol. 2011; 122(1): 11-9.

PubMed Abstract | Publisher Full Text

56. F Ilie M, Long-Mira E, Funck-Brentano E, et al.: Immunohistochemistry as a potential tool for routine detection of the NRAS Q61R mutation in patients with metastatic melanoma. J Am Acad Dermatol. 2015; 72(5): 786-93. PubMed Abstract | Publisher Full Text | F1000 Recommendation

57. Anderson S, Bloom KJ, Vallera DU, et al.: Multisite analytic performance studies of a real-time polymerase chain reaction assay for the detection of BRAF V600E mutations in formalin-fixed, paraffin-embedded tissue specimens of malignant melanoma. Arch Pathol Lab Med. 2012; 136(11): 1385-91. PubMed Abstract | Publisher Full Text 


\section{Open Peer Review}

\section{Current Peer Review Status:}

\section{Editorial Note on the Review Process}

Faculty Reviews are review articles written by the prestigious Members of Faculty Opinions. The articles are commissioned and peer reviewed before publication to ensure that the final, published version is comprehensive and accessible. The reviewers who approved the final version are listed with their names and affiliations.

\section{The reviewers who approved this article are:}

\section{Version 1}

\section{Pedram Gerami}

Department of Dermatology, Northwestern University, Chicago, IL, USA

Competing Interests: No competing interests were disclosed.

\section{Lyn Duncan}

Department of Pathology, Massachusetts General Hospital and Harvard Medical School, Boston, MA, USA

Competing Interests: No competing interests were disclosed.

\section{Heinz Kutzner}

Department of Dermatology, Dermatopathologie Friedrichshafen, Friedrichshafen, Germany

Competing Interests: No competing interests were disclosed.

The benefits of publishing with F1000Research:

- Your article is published within days, with no editorial bias

- You can publish traditional articles, null/negative results, case reports, data notes and more

- The peer review process is transparent and collaborative

- Your article is indexed in PubMed after passing peer review

- Dedicated customer support at every stage

For pre-submission enquiries, contact research@f1000.com 